\title{
Role of Oil Cakes and Pochonia chlamydosporia for the Management of Meloidogyne javanica Attacking Solanum melongena L
}

\author{
Kavita Parihar*, Bushra Rehman, Mohamad Ashraf Ganai, Mohd Asif and Siddiqui Mansoor A
}

Section of Plant Pathology and Plant Nematology Department of Botany, Aligarh Muslim University, Aligarh (U.P.) 202002, India

\begin{abstract}
A pot experiment was conducted to evaluate the efficacy of Pochonia chlamydosporia, oil cakes of neem, mustard and cotton and nematicide (carbofuran) in the management of root knot nematode, Meloidogyne javanica infecting brinjal under glasshouse conditions. All the treatments were effectively suppressed the nematode population and kept the infection at significantly low levels. Among oilcakes individual treatment of neem was more effective than other oil cakes in controlling $M$. javanica, whereas among combined treatment, neem cake $+P$. chlamydosporia was more effective in the management of $M$. javanica followed by mustard cake+P. chlamydosporia and cotton cake $+P$. chlamydosporia. However, the efficacy of $P$. chlamydosporia increased in the presence of oilcakes. Oilcakes when combined with nematicide (carbofuran) showed best results in terms of plant growth parameters, reduce root knot diseases and nematode multiplication after combining with $P$. chlamydosporia. These organic amendments are capable of producing secondary metabolites, which have an allelopathic effect and induces plant resistance against the invasion of nematodes. This approach is non hazardous, cheaper and easily available to the farmers.
\end{abstract}

Keywords: S. melongena; Integrated approach; Oilcakes; Nematicide; P. chlamydosporia

\section{Introduction}

Plant parasitic nematodes are responsible for agricultural losses worldwide, amounting to an estimated $\$ 157$ billion annually [1]. The root knot nematodes (Meloidogyne spp.) are most damaging plant pests and seriously affect many economically important crops worldwide [2]. Most of the vegetables, horticultural crops, spices and pulses are highly susceptible to root knot infection [3]. In order to combat the plant parasitic nematode problem, lot of the chemical pesticides are used by the farmers and agricultural pratitioners for better yield. These chemicals are frequently applied around the year and it accounts for $13-14 \%$ of total pesticide consumption as against $2.6 \%$ of cropped area [4]. Chemical pesticides exposure had been associated with ground water contamination and human health risks. Unjudicious use of these pesticides lead to accumulation of chemicals in leaves, vegetables and fruits. This has created the possibility to use biocontrol agents to reduce population density of plant parasitic nematodes and nematophagous fungi for nematode biological control. Nematophgous fungi are common soil inhabitants, infecting living nematodes through different strategies. Plant parasitic nematodes generally attack plant roots, therefore the ability of nematophogous fungi to colonize roots should be a great advantage.

Pochonia chlamydosporia (Goddard) Zare and Gams is facultative parasite of eggs and female nematodes has been studied as a biocontrol agent. This fungus wraps itself around the eggs, penetrate the egg shell and destroys eggs with the help of proteases enzymes [5,6]. $P$. chlamydosporia isolated from root-knot nematodes (Meloidogyne spp.) [7] and cyst nematodes such as Heterodera spp., Globodera spp. [8]. This biocontrol agent can maintain its population densities and survival upto five months in in vitro, which makes this fungus suitable biocontrol agent [9].

Eggplant, Solanum melongena L., is one of the important vegetable crops in India and is widely cultivated. India is the second largest producer of eggplants $(11896000 \mathrm{mt})$ in world production wise (FAO, 2011) [10]. Vegetables are essential components of our routine diet due to their nutritional value. These play a significant role as sources of vitamins (C, A, B6, thiamine, niacin, E), minerals, and dietary fiber.
Nonchemical methods such as cultural, regulatory and biological methods can be good substitutes for chemicals and provide satisfactory management of root-knot disease in vegetables and other crops (Khan) [11]. Among numerous biocontrol agents viz. P. chlamydosporia (Kerry, Siddiqui et al.) [6,12] P. lilacinus (Thom) Samson (Khan et al.) [13] and T. harzianum (Bokhari) [14] shown antagonism against rootknot nematodes and found to be highly suppressive to plant nematodes, in greenhouse as well as in field [11]. But in field trials, these biocontrol agents usually do not show same level control of nematodes. When biocontrol agents integrated with oil cakes showed best results. The oil cakes contributing to NPK, apart from this, oil cakes having a greater benefit in the agriculture, which none of the pesticide or synthetic fertilizer can perform. They provide slow and steady nourishment and protection to host plant; create antagonistic micro flora and fauna for pathogens, including soil nematodes Oil cakes retard nitrification of the soil/urea and thereby increase $\mathrm{N}$ uptake by the plants oil cakes containing $2-7 \%$ of protein $\mathrm{N}$ applied at @ of 4-10\%suppress soil nematodes and improve plant tree health [15]. The residual effect of various oil cakes against plant parasitic nematodes has been reported in the succeeding crops [16].

In the present paper, an attempt was made to use oil seed cakes of cotton, mustard and neem, those become available in the market throughout the year to control root knot nematodes with $P$. chlamydosporia. To attain this objective, a pot house trial was undertaken to determine the effectiveness of cotton, mustard and neem oil seed cakes singly and in combination with $P$. chlamydosporia against root knot disease of eggplant (S. melongena L. cv. neelam) caused by

*Corresponding authors: Kavita Parihar, Section of Plant Pathology and Plant Nematology Department of Botany, Aligarh Muslim University, Aligarh, U.P, India, Tel: 0571270 0935; E-mail: rnakavi@gmail.com

Received May 11, 2015; Accepted June 15, 2015; Published June 25, 2015

Citation: Parihar K, Rehman B, Ganai MA, Asif M, Siddiqui Mansoor A (2015) Role of Oil Cakes and Pochonia chlamydosporia for the Management of Meloidogyne javanica Attacking Solanum melongena L. J Plant Pathol Microbiol S1: 004 doi:10.4172/2157-7471.S1-004

Copyright: ( 2015 Parihar K, et al. This is an open-access article distributed under the terms of the Creative Commons Attribution License, which permits unrestricted use, distribution, and reproduction in any medium, provided the original author and source are credited. 
M. javanica (Treub) Chitwood. The effects of the treatments were also compared with nematicide, carbofuran $(3 \mathrm{G})$.

\section{Materials and Methods}

\section{Host plant and pathogen}

Seeds of Brinjal (Solanum melongena L. cv. Neelam) was obtained from local market and surfaced sterilized with $0.01 \% \mathrm{HgCl}_{2}$ for two minutes and sown in the plastic tray in greenhouse in Deptt. Of Boatny, AMU, Aligarh. Then three weeks old seedlings were transplanted in autoclaved soil in clay pots $(15 \mathrm{~cm}$ in diameter) containing $1 \mathrm{~kg}$ sterilized soil and farmyard manure in 3:1 mixture. The root-knot nematode M. javanica (Treub) Chitwood, 1949 was selected as test pathogen.

\section{Root knot nematode culture}

The healthy eggmasses of root-knot nematode, M. javanica was collected from the infected roots of brinjal, S. melongena L. Family Solanaceae (collected from a heavily infected brinjal field near Sasni, Agra Road, Hathras) and placed on a small coarse sieve (1 mm pore size) lined with tissue paper and placed in $10 \mathrm{~cm}$ diameter Petridish containing double distilled water. The second stage juveniles, which hatched out, were collected along with water from the Petridish. The infective second stage juveniles of $M$. javanica in water suspension was adjusted so that 1000 freshly hatched juveniles could be added in $10 \mathrm{ml}$ of water suspension, used for in vitro test and served as initial inoculum level for glasshouse experiments. The nematode species was ascertained by close examination of perineal pattern of the female from the first eggmass collected. It was confirmed by similar examination of the randomly collected females from the inoculum raised as above.

\section{Preparation of oil seed cakes and nematicide}

Oil seed cakes of different plant species viz., Neem (Azadirachta indica A. Juss), Mustard (Brassica juncea L.) and Cotton (Gossypium herbaceum L.) were used to control M. javanica infesting eggplant. All these oil cakes were dried, grinded finely in electric grinder and applied @25 g/pot before transplanting the eggplant seedling. A nematicide Carbofuran/Furadan 3-G (2,3-dihydro-2,2-dimethyl 7-benzo-furanyl methyl carbamate), was also applied @ 1 g/pot one week before taransplanting. These pots were watered properly for decomposition of oil seed cakes. After two weeks of decomposition, the eggplant seedlings were transplanted in oilseed cakes treated pots.

\section{Fungal culture preparation and inoculation}

Pure culture of Pochonia chlamydosporia was obtained from Indian Agricultural Research Institute (IARI), New Delhi. The fungal culture was maintained on PDA [17] autoclaved at $15 \mathrm{lbs}$ for 15 minutes in 250 $\mathrm{ml}$ conical flask. The fungus was colonized by using Richards liquid medium, incubated at $25 \pm 2^{\circ} \mathrm{C}$ for 15 days in BOD. After that mass of fungal growth was obtained in the form of mycelial mat. This mat was collected and blended with the known volume of double distilled water in electric blender for $30 \mathrm{sec}$. The fungal suspension of $P$. chlamydosporia containing $2 \mathrm{~g}$ mycelium with spores/pot, was added to the soil around seedlings root before transplanting.

\section{Nematode inoculation and experimental design}

Three week old plants were inoculated with M. javanica (1000 J2/ pot) suspensions into depressions (1.5-cm-diam. by 3- and 4-cm deep) surrounding the bases of the plants. The experimental design for each test was a complete randomized block with 4 replications. There were four replicates for each treatment including the untreated uninoculated and untreated inoculated control. Treatments were given as follows.

\author{
$\mathrm{T} 1=$ Cotton cake \\ $\mathrm{T} 2=$ Cotton cake + Carbofuran \\ $\mathrm{T} 3=$ Cotton cake $+P$. chlamydosporia \\ T4=Mustard cake \\ T5=Mustard cake+Carbofuran \\ T6=Mustard cake $+P$. chlamydosporia \\ $\mathrm{T} 7=$ Neem cake \\ $\mathrm{T} 8=$ Neem cake + Carbofuran \\ $\mathrm{T} 9=$ Neem cake $+P$. chlamydosporia \\ T10=Untreated Uninoculated \\ T11=Untreated Inoculated
}

\section{Plant growth characters}

Plants were uprooted after 60 days from the date of inoculation, four replicates were gently lifted from the pots and washed with tap water taking utmost care to avoid loss or injury to the roots during the complete operation, the excess water of plants was removed by putting them between the folds of blotting sheets. The different plant growth parameters including length in terms of centimeters $(\mathrm{cm})$, fresh and dry weight in terms of grams $(\mathrm{g})$ of shoots and roots were determined separately.

\section{Chlorophyll and carotenoid content}

The chlorophyll content in the fresh leaf was estimated following method worked out by Mackinney [18]. One g of finely cut fresh leaves was ground to a fine pulp using a mortar and pestle after pouring $20 \mathrm{~cm}^{3}$ of $80 \%$ acetone The mixture was centrifuged at 5,000 rpm for 5 minutes. The supernatant was collected in $100 \mathrm{~cm}^{3}$ volumetric flask. The residue was washed three times using $80 \%$ acetone. Each washing was collected in the same volumetric flask and volume was made upto the mark, using $80 \%$ acetone. The absorbance in terms of optical density was read at 645 and $663 \mathrm{~nm}$ for chlorophyll and 480 and $510 \mathrm{~nm}$ for carotenoid against the acetone (80\%) as blank on spectrophotometer (UV.1700, Shimadzu, Japan). The chlorophyll and carotenoid contents present in the extracts of leaves was calculated according to the equation given by Arnon.

Total chlorophyll $\left(\mathrm{mg} \mathrm{g}^{-1}\right.$ leaf fresh mass $)=\left(20.2(O D\right.$ 645) $+8.02(O D$ 663) $)) \times \frac{V}{1000 \times W}$

Carotenoid $\left(\mathrm{mg} \mathrm{g}^{-1}\right.$ leaf fresh mass $=\frac{7.6(O D 480)-1.49(\mathrm{OD} 510)}{d \times 1000 \times W} \times V$

Where,

OD645, OD663, OD480, OD510=Optical densities at 480, 663, 480 and $510 \mathrm{~nm}$ respectively

$\mathrm{V}=$ Volume of an extract

$\mathrm{W}=$ Mass of leaf tissues

$\mathrm{d}=$ Length of light path $(\mathrm{d}=1.4 \mathrm{~cm})$

\section{Nematode population and reproduction factor}

The nematode population in soil from every replicate was determined by processing $250 \mathrm{~g}$ of soil using Cobb's sieving and 
decanting method along with Baermann's funnel technique (Southey) [19]. The root knot index were expressed on a 0-5 scale according to Taylor and Sasser [20] ( $0=$ no galling; $1=1-2$ galling; $2=3-10$ galling; $3=11-30$ galling; $4=31-100$ galling; and $5=$ more than 100 galls $/$ root system).

\section{Statistical analysis}

Statistical analyses were performed using using SPSS 12.00 software (SPSS Inc., Chicago, IL, USA). Least significant differences (L.S.D) were calculated at $p=0.05$ level to test for significant differences.

\section{Results and Discussion}

\section{In vitro experiment (egg parasitism by $P$. chlamydosporia)}

$P$. chlamydosporia is an egg parasitic fungi which parasitized eggs of M. javanica at various degree of extent. In Figure 1a P. chlamydosporia clearly showed higher degree of parasitism (95.3\%) at 5 egg masses/petri plates. There was a positive correlation between number of egg masses and egg parasitism i.e. when egg masses increased the corresponding increase in egg parasitism were found.

\section{Glasshouse experiments}

Data depicted in Table 1, clearly showed that $P$. chlamydosporia had the potential to reduce population density of $M$. javanica infecting brinjal. The oil cakes significantly enhanced the all growth and physiological parameters, however combined treatment of oil cakes and P. chlamydosporia also found more effective as compared to alone treatment. On the other hand Carbofuran in combination with oil cakes (cotton, neem, mustard) at par with P. chlamydosporia treatments. Among the growth parameters the maximum shoot length $(42.4 \mathrm{~cm})$, fresh shoot weight $(29.3 \mathrm{~g})$, shoot weight $(20.0 \mathrm{~g})$, root length $(22.5 \mathrm{~cm})$, fresh root weight $(19.3 \mathrm{~g})$, dry root weight $(12.7 \mathrm{~g})$ were recorded in the treatment T8 (neem cake+carbofuran) and found minimum $20.5 \mathrm{~cm}, 16.5 \mathrm{~g}, 8.3 \mathrm{~g}, 11.4 \mathrm{~cm}, 9.7 \mathrm{~g}$ and $6.2 \mathrm{~g}$ respectively in T11(nematode only). Among all the treatments carbofuran and $P$. chlamydosporia were found at par in combination with neem cake. T8 treatment were found most effective in controlling disease while T1 showed least effective in terms of shoot length $(25.4 \mathrm{~cm})$, fresh shoot weight (19.5), dry shoot weight (10.3 g), root length (12.6), fresh root weight (11.4), dry root weight $(10.3 \mathrm{~g})$ respectively. The yield/pot was maximum $233.4 \mathrm{~g}$ in $\mathrm{T} 8$ and minimum was in $\mathrm{T} 1142.5 \mathrm{~g}$ as compared to untreated uninoculated control $(246.2 \mathrm{~g})$. Other treatments were also exhibited satisfactory results to reduce disease intensity in pots $(\mathrm{T} 7>\mathrm{T} 5>\mathrm{T} 2>\mathrm{T} 6>\mathrm{T} 3>\mathrm{T} 4)$. The number of females were found less in T9 (27.3), maximum in T1(51.5), while other treatments were showed effectiveness towards reducing disease intensity.

In Figures $1 \mathrm{~b}$ and $1 \mathrm{c}$ showing that physiological parameters viz., chlorophyll and carotenoid content were also be enhanced by the treatments of various oil cakes, $P$. chlamydosporia and nematicide. Among all treatments T9 found most effective and T1 was least effective. The root knot index were found minimum in treatment T8 and maximum in T11 (untreated inoculated control) (Figure 1d).

The inhibitory effect of plant extracts reviewed by many workers in various plant species and it might be due to the chemicals calotropin present in Calotropis sp., thujone in Thuja sp., polythenyls in Tagetes sp. [21], isothiocyanates and glucosinolates from Brassicaceae, polyacetylene from Asteraceae [22] possess nematicidal effect $[23,24]$.
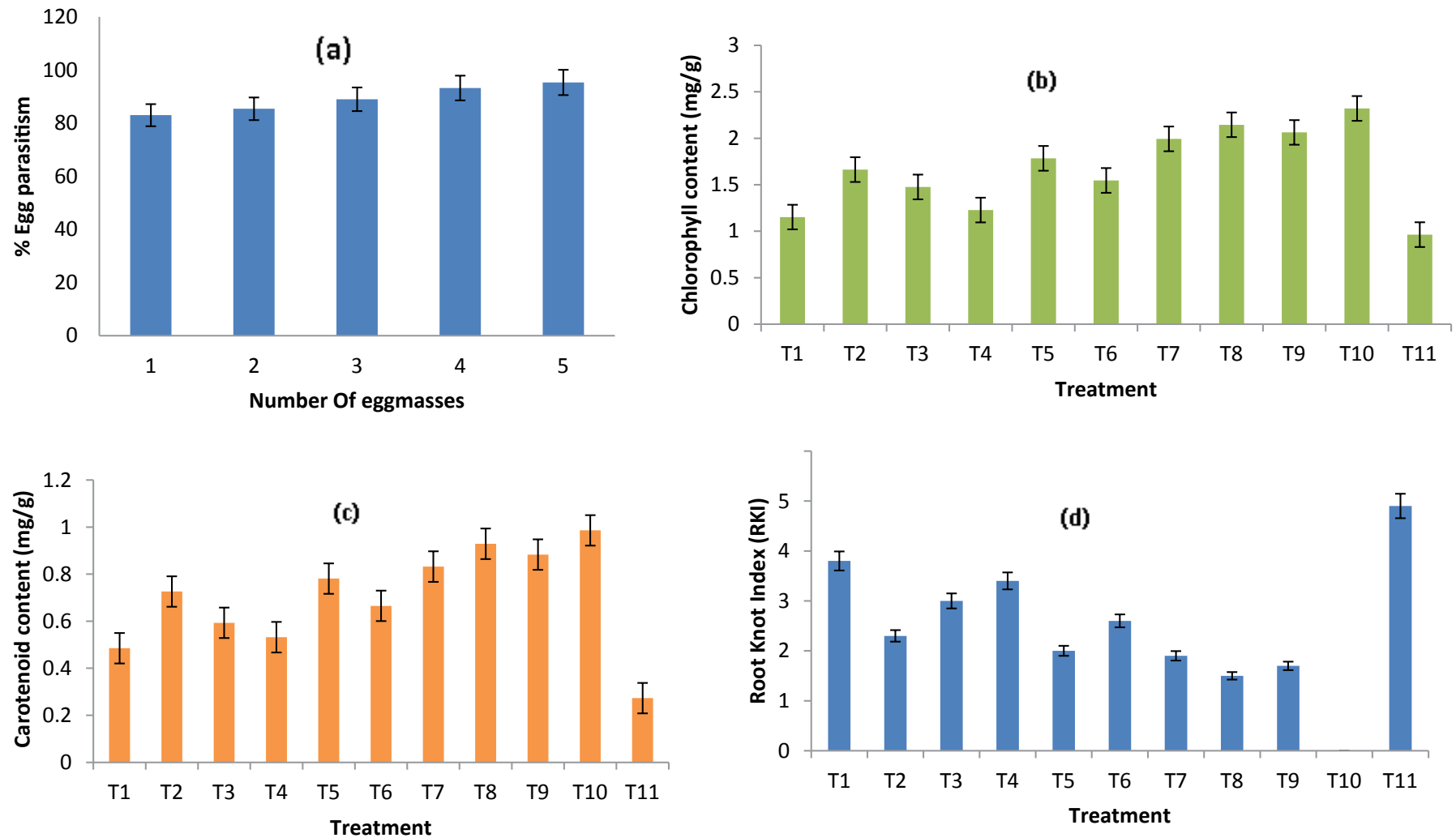

Figure 1: (a-d) Showing the effect of oil cakes, $P$. chlamydosporia and Carbofuran on physiological and pathological parameters against $M$. javanica in brinjal cv. Neelam. 
Citation: Parihar K, Rehman B, Ganai MA, Asif M, Siddiqui Mansoor A (2015) Role of Oil Cakes and Pochonia chlamydosporia for the Management of Meloidogyne javanica Attacking Solanum melongena L. J Plant Pathol Microbiol S1: 004. doi:10.4172/2157-7471.S1-004

Page 4 of 5

\begin{tabular}{|c|c|c|c|c|c|c|c|c|c|c|c|c|c|c|c|c|}
\hline \multirow{2}{*}{ Treatments } & \multicolumn{4}{|c|}{ Length $(\mathrm{cm})$} & \multicolumn{4}{|c|}{ Fresh weight (g) } & \multicolumn{4}{|c|}{ Dry weight (g) } & \multirow{2}{*}{ Yield (g) } & \multirow{2}{*}{$\%$ var. } & \multirow{2}{*}{$\begin{array}{l}\text { No. Of } \\
\text { females }\end{array}$} & \multirow{2}{*}{$\%$ var. } \\
\hline & Shoot & $\%$ var. & Root & $\%$ var. & Shoot & $\%$ var. & Root & $\%$ var. & Shoot & $\%$ var. & Root & $\%$ var. & & & & \\
\hline T1 & 25.4 & 47.41 & 12.6 & 47.5 & 19.5 & 39.45 & 11.4 & 48.87 & 10.3 & 51.86 & 7.4 & 48.96 & 142.5 & 42.12 & 51.1 & 9.96 \\
\hline $\mathrm{T} 2$ & 32.3 & 33.12 & 16.7 & 30.41 & 23.3 & 27.63 & 15.2 & 31.83 & 16.5 & 22.89 & 10.5 & 27.58 & 180.7 & 26.60 & 39.7 & 30.59 \\
\hline T3 & 29.2 & 39.54 & 14.4 & 40.0 & 21.4 & 33.54 & 13.6 & 39.01 & 12.2 & 42.99 & 9.6 & 33.79 & 160.8 & 34.68 & 45.4 & 20.62 \\
\hline T4 & 27.3 & 43.47 & 13.8 & 42.5 & 20.1 & 37.57 & 12.1 & 45.73 & 12.4 & 42.05 & 8.2 & 43.44 & 152.5 & 38.05 & 48.6 & 15.03 \\
\hline T5 & 35.1 & 27.32 & 17.3 & 27.91 & 25.2 & 21.73 & 15.4 & 30.94 & 16.7 & 21.96 & 11.3 & 22.06 & 190.8 & 22.50 & 36.4 & 36.37 \\
\hline T6 & 30.5 & 37.68 & 15.6 & 35.0 & 22.4 & 30.43 & 13.7 & 38.56 & 14.4 & 32.71 & 9.8 & 32.41 & 165.9 & 48.50 & 42.7 & 25.34 \\
\hline $\mathrm{T7}$ & 38.0 & 21.32 & 19.4 & 19.17 & 27.2 & 15.52 & 16.5 & 26.00 & 18.1 & 15.42 & 10.5 & 27.58 & 200.6 & 18.52 & 33.2 & 41.95 \\
\hline T8 & 42.4 & 12.21 & 22.5 & 6.2 & 29.3 & 9.00 & 19.3 & 13.45 & 20.0 & 6.54 & 12.7 & 12.41 & 233.4 & 5.19 & 23.4 & 59.09 \\
\hline T9 & 41.2 & 14.69 & 20.6 & 14.16 & 28.4 & 11.80 & 17.4 & 21.97 & 19.3 & 9.81 & 11.4 & 21.37 & 212.7 & 13.60 & 27.3 & 52.27 \\
\hline T10 & 48.3 & ---- & 24.0 & ---- & 32.2 & ---- & 22.3 & ---- & 21.4 & ----- & 14.5 & ----- & 246.2 & ------ & ---- & 100 \\
\hline $\mathrm{T} 11$ & 20.5 & 57.53 & 11.4 & 52.5 & 16.5 & 48.75 & 9.7 & 56.50 & 8.3 & 61.21 & 6.2 & 57.24 & 128.9 & 57.2 & 57.2 & ---- \\
\hline $\operatorname{LSD}(P=0.05 \%)$ & 1.92 & & 1.68 & & 1.43 & & 1.36 & & 1.28 & & 1.23 & & 1.48 & & 1.81 & \\
\hline
\end{tabular}

Table 1: Effect of oil cakes alone and combination with P.chlamydosporia and carbofuran on plant growth characters of brinjal cv.Neelam against Meloidogyne javanica. Values are mean of four replicates, Initial inoculum level = 1000 second stage juveniles of $M$. javanica /pot, \% var.= percent variation.

This effect of aqueous extracts may possibly be attributed to their high contents of certain oxygenated compounds which are characterized by their lipophilic properties that enable them to dissolve the cytoplasmic membrane of nematode cells and their functional groups interfering with the enzyme protein structure [25]. These chemicals either affected the embryonic development or killed the eggs or even dissolved the eggmass.

M. javanica is sedentary endoparasite, produces galls and eggs that extrude from the root surface although female stays hidden inside the gall. At high temperatures the eggs hatch early and the egg-parasitizing fungi are unable to destroy the eggs. The chitin-degrading bacteria that degrade soil amendments into ammonium can kill most of the nematodes in soil. Many biocontrol agents are showing effectivity at a specific nematode developmental stage. The juveniles of root knot nematode decrease by the colonization of biocontrol agents but not decrease the soil population because this nematode having more than one generation in particular growing season. Root colonization by $P$. chlamydosporia had strong effectiveness and benefits to the host plant in terms of growth parameters, defense mechanism against different pathogens like nematodes, bacteria and fungi [26]. A fungal serine protease, VCP1 involved in enzymatic degradation of protenacious vitelline membrane, the outer layer of the nematode eggshell [27]. The killing effect of $P$. chlamydosporia, P. lilacinus and Arthrobotrys oligospora on fababean under greenhouse conditions, is similar to synthetic nematicide carbofuran and significantly better than the commercial preparation of bioagents [28].

Large number of workers carried out the study that various oil cakes when amended in combination with different nematicides are more effective in reducing the root-knot infestation caused by $M$. incognita and increased the plant growth and yield than either of them alone [29-32]. While combined application of different oil cakes and biocontrol agents have been reported to be an effective approach to minimize the losses caused by various plant parasitic nematodes $[6,33,34]$. Dhawan and Singh [35] reported that the combination of $P$. chlamydosporia, carbofuran and neem cake gave highest yield and suppress no. of eggs and root galling in okra. Similarly, Cannayane and Rajendran [36] recorded that single applications of either $P$. lilacinus, $P$. chalmydosporia and oil cakes suppressed $M$. incognita.

\section{Conclusion}

The use of chemicals are effective in the management of plant parasitic nematodes, but their hazardous effect on the environment, ground water contamination and ill effects on human health create a necessity to search newer and harmless methods of nematode control. Contamination of vegetables and fruits with chemical pesticide residues has been reported by many researchers [37]. Their constant use leads to build up of toxic residues on crop produce, which may exert adverse effect on human health in addition to disturbing ecosystem. This problem is more serious in the case of vegetables as these are oftenly consumed either raw or without much processing or storage. Thus, it can be suggested after thorough study of above mentioned experiments that oil cake and biocontrol agent alone and in combination (Neen cake $+P$. chlamydosporia) enhanced resistance, growth parameters, yield and activate various defense enzyme. These methods could be utilized by farmers in easy way and without causing any harm to soil flora and fauna. Therefore, It can be suggested that effect of oilcakes and biocontrol agent ( $P$. chlamydosporia) on root knot disease caused by $M$. javanica on brinjal had deleterious effect and the use of these non chemicals also improve yield and palnt growth parameters.

\section{References}

1. Abad P, Gouzy J, Aury JM, Castagnone-Sereno P, Danchin EG, et al. (2008) Genome sequence of the metazoan plant-parasitic nematode Meloidogyne incognita. Nat Biotechnol 26: 909-915

2. Wesemael WML, Viaene N, Moens M (2010) Root-knot nematodes (Meloidogyne spp.) in Europe. Nematology 13: 3-16.

3. Khan MW, Khan MR, Khan AA (1984) Identity of root-knot nematodes on certain vegetables of Aligarh district in northern India. International Nematological Network News 1: 6-7.

4. Sardana HR (2001) Integrated Pest Management in Vegetables, In Training Manual 2, Training on IPM for Zonal Agricultural Research Stations (May 2126). pp. $105-118$.

5. Esteves I, Peteira B, Atkins SD, Magan N, Kerry B (2009) Production of extracellular enzymes by different isolates of Pochonia chlamydosporia. Mycol Res 113: 867-876.

6. Kerry BR (2000) Rhizosphere interactions and the exploitation of microbia agents for the biological control of plant-parasitic nematodes. Annu Rev Phytopathol 38: 423-441

7. Hidalgo-Díaz L, Bourne JM, Kerry BK, Rodríguez MG (2000) In soils infested with Meloidogyne spp. in Cuba: Isolation and screening. Int J Pest Manage 46: 277-284.

8. Kerry BR, Crump DH (1977) Observations on fungal parasites of females and eggs of the cereal cyst-nematode, Heterodera avenae, and other cyst nematodes. Nematologica 23: 193-201.

9. Atkins SD, Hidalgo-Diaz L, Kalisz H, Mauchline TH, Hirsch PR, et al. (2003) Development of a new management strategy for the control of root-knot nematodes (Meloidogyne spp) in organic vegetable production. Pest Manag Sci 59: 183-189. 
Citation: Parihar K, Rehman B, Ganai MA, Asif M, Siddiqui Mansoor A (2015) Role of Oil Cakes and Pochonia chlamydosporia for the Management of Meloidogyne javanica Attacking Solanum melongena L. J Plant Pathol Microbiol S1: 004. doi:10.4172/2157-7471.S1-004

10. FAO (2011) FAO statistical database division retrieved on 15 May, 2014.

11. Khan MR (2007) Prospects of microbial control of root-knot nematodes infecting vegetable crops. In: Singh NS. ed. Biotechnology: Plant Health Management International Book Distributing Co. pp. 643-665.

12. Siddiqui IA, Atkins SD, Kerry BR (2009) Relationship between saprotrophic growth in soil of different biotypes of Pochonia chlamydosporia and the infection of nematode eggs. Ann Appl Biol 155: 131-141.

13. Khan MR, Khan SM, Mohide F (2005) Root-knot Nematode Problem of Some Winter Ornamental Plants and Its Biomanagement. J Nematol 37: 198-206.

14. Bokhari FAM (2009) Efficacy of some Trichoderma species in the control of Rotylenchulus reniformis and Meloidogyne javanica. Arch Phytopathol Plant Protect 42: 361-369.

15. Tiyagi SA, Khan AV, Alam MM (2002) Biodegradable effect of oil seed cakes on plant-parasitic nematodes and soil inhabiting fungi infesting Trigonella foenumgreacum and Phaseous aureus. Indian Journal of Nematology 32: 47-57.

16. Akhtar M, Malik A (2000) Roles of organic soil amendments and soil organisms in the biological control of plant-parasitic nematodes: a review. Bioresource Technology 74: 35-47.

17. Riker AJ, Riker RS (1936) Introduction to research on plant diseases. John's swift Co. Inc., St. Louis, Chicago NY, p. 117

18. Mackinney G (1941) Absorption of light by chlorophyll solutions. J Biol Chem 140: $315-322$.

19. Southey JF (1986) Laboratory methods for work with plant and soil nematodes p. 202.

20. Taylor AL, Sasser JN (1978) Biology, identification and control of root-knot nematodes (Meloidogyne spp.) NCSU Graphics Raleigh, NC, USA, p. 111

21. Kyo M, Miyauchi Y, Fujimoto T, Mayama S (1990) Production of nematocidal compounds by hairy root cultures of Tagetes patula L. Plant Cell Rep 9: 393397.

22. Kogiso S, Wada K, Munakata K (1976) Isolation of nematicidal polyacetylenes from Carthamus tinctorius L. Agric Biol Chem 40: 2085-2089.

23. Khurma UR, Chaudhary P (1999) Comparative effects of extracts of different parts of Calotropis procera, Cassia fistula, Ricinus communis and Sesbania sesban on Meloidogyne javanica juveniles. J Environ Biol 20: 287-288.

24. Saravanpriya B, Shivakumar M, Rajendran M, Kuttalam S (2004) Effect of different plant products on the hatching of Meloidogyne incognita eggs. Indian J Nematol 34: 40-43.

25. Knoblock K, Weis N, Wergant R (1989) Mechanism of antimicrobial activity of essential oils. 37th Ann Cong Med Plant Res Braunschweig 5-9.
26. Siddiqi ZA, Akhtar MS (2008) Synergistic effects of antagonistic fungi and a plant growth promoting rhizobacterium, an arbuscular mycorrhizal fungus, or composted cow manure on populations of Meloidogyne incognita and growth of tomato Biocontrol Sci. Techn 18: 207-290.

27. Morton OM, Hirsch PR, Kerry BR (2004) Infection of Plant-parasitic Nematodes by Nematophagous Fungi. A Review of the Application of Molecular Biology to Understand Infection Processes and to Improve Biological Control. Nematology 6: 161-170.

28. Abd El R, El Shan S, Samir A El Sayed, Yehia AG, Doae Mahmoud MK (2005) Evaluation of Pochonia chlamydosporia, Paecilomyces lilacinus and Arthrobotrys oligospora as biocontrol agents for Meloidogyne incognita under green house conditions. Pak J Biol Sci 1511-1516.

29. Sankaranarayana C, Sundarababu R (1997) Effect of oil cakes and nematicides on the growth of Black gram inoculated with VAM fungus (Glomus fasciculatum) and root-knot nematode (Meloidogyne incognita)Indian J Nematol 27: 128-130.

30. Goswami BK, Pandey RK, Rathour KS, Bhattacharya C, Singh L (2006) Integrated application of some compatible biocontrol agents along with mustard oil seed cake and furadan on Meloidogyne incognita infecting tomato plants. J Zhejiang Univ Sci B 7: 873-875.

31. Rather MA, Ahmad F, Siddiqui MA (2007) Combined influence of Neem part/ products and /or low nematicides against root-knot nematode, Meloidogyne incognita on field grown tomato. Pak J Nematol 25: 305-311.

32. Ahmad F, Rather MA, Siddiqui MA (2008) Control of Meloidogyne incognita root-knot nematode on eggplant with organic amendments and nematicides. Pak J Nematol 26: 83-89.

33. Borah A, Phukan PN (2004) Comparative efficacy of Glomus fasciculatum with neem cake and carbofuran for the management of Meloidogyne incognita on brinjal. Indian J Nematol 34: 129-132.

34. Zareena BM, Kumar SM (2005) Management of disease complex involving Heterodera cajani koshy, 1967 and Macrophomina phaseolina (Tassi) Goid on greengram (Vigna radiata L. Wilezek). Indian. J Nematol 35: 192-194.

35. Dhawan SC, Singh S (2009) Compatibility of Pochonia chlamydosporia with nematicide and neem cake against root knot nematode, Meloidogyne incognita infesting okra. Indian J Nematol 39: 85-89.

36. Cannayane I, Rajendran G (2001) Application of biocontrol agents and oil cakes for the management of Meloidogyne incognita in brinjal. Curr Nematol 12: $51-55$.

37. Kumari B, Kumar R, Madan VK, Singh R, Singh J, et al. (2003) Magnitude of pesticidal contamination in winter vegetables from Hisar, Haryana. Environ Monit Assess 87: 311-318.
This article was originally published in a special issue, Plant Pathology handled by Editor(s). Dr. Tadayuki Iwase, Jikei University School of Medicine 